\title{
Prevalence of Irritable Bowel Syndrome and its Association with Psychological Distress among Female College Students in Korea
}

\author{
Aelee Jang ${ }^{\dagger}, *$ \\ Department of Nursing, University of Ulsan, Ulsan 44610, Korea
}

\begin{abstract}
It is well known that irritable bowel syndrome (IBS) is related to psychological distress. However, only a few studies have investigated the relationship between IBS and various dimensions of psychological distress. This study aimed to evaluate the prevalence of IBS and its relationship with anxiety, depression, and stress in young female college students. A cross-sectional study was conducted using a self-report structured questionnaire with 673 female college students. IBS was diagnosed based on the Rome III criteria. For the evaluation of psychological distress on the IBS, we investigated Hospital Anxiety and Depression Scale (HADS) and Global Assessment of Recent Stress (GARS). The prevalence of IBS was $27.9 \%$. In the univariate analysis, the anxiety, depression, and stress scores were significantly associated with IBS $(P<0.001, P=0.001$, and $P<0.001$, respectively). Multivariate analysis showed that anxiety $(\mathrm{OR}=1.07,95 \% \mathrm{CI}=1.01 \sim$ $1.15, P=0.032)$ and stress scores $(\mathrm{OR}=1.23,95 \% \mathrm{CI}=1.19 \sim 1.27, P<0.001)$ were independently correlated with the IBS. Among the subtypes of IBS, IBS with predominant constipation was the most common, and the anxiety, depression, and stress scores did not significantly differ between the subtypes. Our results suggest that anxiety and stress are closely related to IBS. Managing psychological distress should be considered in the treatment of IBS in young female college students.
\end{abstract}

Key Words: Irritable bowel syndrome, Female, Student, Psychological distress, Anxiety, Depression, Stress

\section{서 론}

과민성 대장증후군(irritable bowel syndrome, IBS)은 복 통, 복부 불편감 및 대변습관의 변화를 특징으로 하는 만 성 질환이다(Mearin et al., 2016; Ford et al., 2017). 전 세계적 으로 약 4 22\%의 유병률을 보이는 매우 흔한 질환이다 (Hungin et al., 2003; Choung and Locke, 2011; Makharia et al., 2011). 대부분 35 세 이전에 증상이 발생하고, 25 세 이하에 서 증상이 가장 많이 나타나며(Thomson and Dancey, 1996; Han et al., 2006; Naeem et al., 2012), 젊은 여성에서 남성보 다 3 배 정도 더 많이 발생하는 것으로 보고되고 있다(Lee et al., 2001; Chang and Heitkemper, 2002). 특히, 대학생을
대상으로 실시된 연구에서 과민성 대장증후군의 유병률이 $10.7 \sim 24.0 \%$ 로 관찰되고, 여자대학생에서는 $15.7 \sim 35.0 \%$ 로 남자대학생보다 높은 빈도로 보고되고 있다(Jafri et al., 2005; Shiotani et al., 2006; Naeem et al., 2012; Ibrahim et al., 2013; Costanian et al., 2015; Alsuwailm et al., 2017). 하위 유형 은 증상에 따라 변비형(IBS with predominant constipation), 설사형(IBS with predominant diarrhea), 혼합형(IBS with mixed bowel habits), 미분류형(unsubtyped IBS)으로 분류하 는데, 남성은 설사형, 젊은 여성에서는 변비형이 우세한 것으로 알려져 있다(Chial and Camilleri, 2002; Adeyemo et al., 2010; Kim and Kim, 2018).

과민성 대장증후군의 정확한 병태생리는 아직 알려져 있지 않지만, 내장의 감각과민 및 자율신경계의 부적절한

Received: November 23, 2020 / Revised: December 15, 2020 / Accepted: December 15, 2020

* Professor.

${ }^{\dagger}$ Corresponding author: Aelee Jang. Department of Nursing, University of Ulsan, Daehak-ro 93, Nam-gu, Ulsan 44610, Korea.

Tel: +82-52-259-1252, Fax: +82-52-259-1236, e-mail: aeleejang@ulsan.ac.kr

(C) The Korean Society for Biomedical Laboratory Sciences. All rights reserved.

(C) This is an Open Access article distributed under the terms of the Creative Commons Attribution Non-Commercial License (http://creativecommons.org/licenses/by-nc/3.0/) which permits unrestricted non-commercial use, distribution, and reproduction in any medium, provided the original work is properly cited. 
변화로 인하여 복통이나 복부 불편감이 나타나며(Mazurak et al., 2012), 불안, 우울, 스트레스와 같은 정신적 요인이 과민성 대장증후군을 유발하는데 중요한 역할을 할 것으 로 생각된다(Azpiroz et al., 2000; Whitehead et al., 2002; Chey et al., 2015). 생체심리사회적 모델(biopsychosocial model) 에서는 뇌와 장 사이에 상호작용(brain-gut axis)으로 심리 적 고통이 생리적 기능에 영향을 미쳐 신체화 증상이 나 타난다고 설명하고 있다(Drossman, 1998; Jones et al., 2011; Tanaka et al., 2011). 따라서, 과민성 대장증후군은 중추신 경계와 다양한 심리적 고통의 상호작용이 장의 연동운동 과 통증에 대한 민감도에 영향을 미쳐 일어난다는 가능 성에 대해 설명된다(Porcelli, 2004).

과민성 대장증후군은 생명을 위협할 수 있는 중한 질환 은 아니지만 반복되는 증상들로 인해 삶의 질이 크게 저 하된다(Lu et al., 2005; Chey et al., 2015). 많은 환자들은 과 민성 대장증후군의 증상 악화로 일상적인 생활에 불편을 느끼고, 사회생활을 제대로 하지 못하여 학교를 결석하거 나 직장을 결근하게 된다. 또한, 불편감으로 약물을 복용 하거나 필요 없는 검사를 받게 되어 의료비의 지출이 현 저히 증가하는 등의 문제가 발생할 수 있다(Azpiroz et al., 2000; Whitehead et al., 2002; Spiegel, 2009). 그러므로 쉽게 간과되고 있는 과민성 대장증후군에 대한 정확한 진단이 발생확률이 높은 젊은 여성들에게 필요하다.

과민성 대장증후군 환자에서 정신적 문제를 동반한 경 우가 있는 것으로 알려져 있으며(Esler and Coulston, 1973; Rose et al., 1986; Savas et al., 2009), 지금까지 몇몇 연구에 서 불안, 우울, 스트레스 등과 관련된 심리적 고통의 유 병률을 과민성 대장증후군 환자와 정상 성인을 비교연구 하였다. 심리적 고통이 정상 성인에 비하여 과민성 대장 증후군 환자에게 더 심하다고 보고한 선행연구도 있으나 (Savas et al., 2009; Sugaya et al., 2012), 차이가 없다고 보고한 연구들도 있었다(Alander et al., 2008; Berman et al., 2012) 또 한, 심리적 고통을 동반한 과민성 대장증후군 환자는 변 비형을 더 많이 나타낸다는 보고도 아직 논란의 여지가 있다(Muscatello et al., 2010).

따라서 본 연구에서는 젊은 여자대학생을 대상으로 과 민성 대장증후군의 유병률과 하위 유형의 분포를 조사하 고 과민성 대장증후군과 불안, 우울 및 스트레스와 같은 심리적 고통과의 연관성을 보고자 하였다.

\section{연구 방법}

\section{연구설계}

본 연구는 국내 여자대학생을 대상으로 과민성 대장증 후군 유병률과 불안, 우울 및 스트레스와 같은 심리적 고 통과의 연관성을 파악하기 위한 서술적 조사연구이다.

\section{연구대상}

연구대상자는 $\mathrm{B}$ 시 소재 4 개의 4 년제 대학교에 재학 중 인 만 18 세 이상 여자대학생 중 연구목적을 이해하고 연 구참여에 자발적으로 동의한 780 명을 임의 표출하였다. 대상자 제외기준으로는 소화기계통 수술을 받았거나 복 통으로 입원한 과거력이 있는 자, 동반되는 기질적 소화 기 질환이 있는 자(염증성 장 질환, 유당흡수 장애, 복강 질환, 폐쇄성 장 질환 등), 중증 복합 면역 결핍증이나 갑 상선 질환이 있는 자, 현재 정신 질환을 않고 있거나 정신 과 약물을 복용하는 자, 장 운동에 영향을 줄 수 있는 약 물을 정기적으로 복용하는 자이다. 모집된 대상자 780 명 중 대상자 제외기준에 해당하는 107 명(참여 거절 90 명, 장 수술의 과거력 10 명, 기질적인 소화기 질환 동반 4 명, 심각한 갑상선 질환 3명)을 제외하고 여자대학생 673명의 자료가 최종분석에 사용되었다(Fig. 1).

\section{연구도구}

과민성 대장증후군: 과민성 대장증후군 진단은 Drossman (2006)에 의하여 개발되고 Rome III에 근거한 Rome III Adult Questionnaire을 대한소화기 기능성 질환 운동학회에 서 한국어로 번역한 도구로 허가를 받은 후 사용하였다 (Song et al., 2013). 총 10문항으로 구성되어 있는 과민성 대장증후군의 구체적인 진단기준으로 1 3번 문항의 복부 통증이나 불편감을 경험한 기간을 측정 등의 과민성 대장 증후군 진단 조건을 만족시키는 경우, A) 4번 문항은 배변 후 증상 완화 관련, B) 5 6번 문항은 복부 통증이나 불편 감의 시작이 배변 횟수와 관련, C) 7 8번 문항은 복부 통 증이나 불편감의 시작이 배변형태와 관련하여 확인한다. 그리고 9 10번 문항은 과민성 대장증후군을 변비형, 설 사형, 혼합형, 미분류형으로 분류하는 문항으로 구성되어 있다.

과민성 대장증후군 진단은 6개월 전부터 복부 통증이 나 복부 팽만감 등 복부 불편감 등의 증상이 시작되었고 진단 시점에서 3 개월 이내 1개월에 2 3일 이상의 빈도를 
보이는 복부 통증이나 불편감이 나타나고, 여성은 복부 통증이나 불편감이 생리기간과 관련 없어야 하며, $\mathrm{A}, \mathrm{B}, \mathrm{C}$ 문항 중 두 개 문항 이상이 과민성 대장증후군의 진단에 만족시켜야 과민성 대장증후군으로 진단내린다. 9번 문항 에 해당되는 경우를 변비형 과민성 대장증후군, 10 번 문 항에 해당되는 경우를 설사형 과민성 대장증후군로 분류 할 수 있다. 9 번과 10 번 문항이 모두 해당되면 혼합형 과 민성 대장증후군으로 모두 해당이 안 되면 미분류형 과 민성 대장증후군으로 분류할 수 있다.

인구사회학적 특성과 건강관련 특성: 설문지는 자가보고 형으로 대상자의 인구사회학적, 건강관련 특성이 포함되 어 있다.

불안과 우울: 불안과 우울에 대한 설문은 Zigmond와 Snaith (1983)에 의해 개발되고 Oh 등 (1999)이 한글로 번 역한 병원 불안 및 우울 도구(Hospital Anxiety and Depression Scale, HADS)를 사용하였는데 도구 개발자와 한글 번 역자의 허가를 받은 후에 측정하였다. 이 도구는 총 14 문 항으로 불안에 관한 척도 7문항과 우울 척도인 7문항으 로 구성되어 있다. 각각의 문항은 0 3점으로 총 0 21점 의 4점 Likert 척도로 점수가 높을수록 불안과 우울이 높 음을 의미한다. 불안과 우울 각각 총점 0 7점은 불안 또 는 우울이 없는 상태, 8 10점은 경계성 불안 또는 우울, 11점 이상은 불안 또는 우울 상태로 정의한다. 한국판 병 원 불안 및 우울 도구의 문항의 내적 일관성에 대한 신 뢰도 Cronbach's $\alpha$ 는 불안 .89, 우울 .89이었으며(Oh et al., 1999), 본 연구에서는 불안 .85 , 우울 .84 였다.

스트레스 지각 정도: 스트레스는 $\operatorname{Linn}$ (1985)에 의해 개발 되고 Koh (1988)이 한글로 번역한 스트레스 지각 정도 도 구(Global Assessment of Recent Stress, GARS)를 이용하여 최근 일주일 동안의 일, 직업 및 학교와 관련된 압박감, 대인관계의 압박감, 대인관계의 변화로 인한 압박감, 병이 나 상해에 의한 압박감, 금전적인 문제로 인한 압박감, 일 상적인 것이 아닌 사건들에 대한 압박감, 일상생활의 변 화유무와 관련된 압박감 및 일주일 간의 전반적인 압박 감 등 8 문항에 대하여 조사하였다. 스트레스가 전혀 없는 경우를 0점으로 하고 극도로 심한 경우를 9점으로 표시 하고, 각각의 문항은 0 9점으로 총 0 72점의 10점 Likert 척도로 점수가 높을수록 스트레스를 지각하는 정도가 높 음을 나타낸다. 도구개발 당시의 검사-재검사 신뢰도는 $r=.69$ 에서부터 $r=.92$ 이었으며(Linn, 1985), 본 연구에서 Cronbach's $\alpha$ 는 .90 이었다.

\section{자료수집}

본 연구에 앞서 $\mathrm{P}$ 대학교병원에서 기관연구윤리심의위 원회(IRB)의 연구승인(D-1204-128-002)을 거쳤고, 자료수 집기간은 2012년 6월부터 2012년 7월까지였다. 자료수집 은 본 연구자 1 인과 연구윤리교육 및 설문조사 훈련을 받은 연구보조원 3 인이 해당 대학의 협조를 얻어 강의시 간 이외의 시간에 연구대상자에게 연구의 목적, 필요성, 방법 등에 대하여 설명을 하고 연구참여에 자발적으로 동의한 학생들에게 설문지를 배부하였다. 연구참여자의 권리를 보호하기 위해 수집된 자료는 익명으로 처리하여 연구가 진행되는 동안 연구의 참여의사를 언제든지 철회 할 수 있음과 연구철회로 인한 어떤 불이익도 받지 않을 것이며 수집된 자료는 연구의 목적으로만 사용할 것임을 설명하였다. 설문지 작성 소요시간은 $15 \sim 20$ 분 정도였으 며, 설문에 참여한 대상자에게 소정의 답례품을 제공하 였다.

\section{자료분석}

수집된 자료는 IBM SPSS Statistics 23.0 program으로 분 석하였다. 여자대학생의 과민성 대장증후군 유병율, 인구 사회학적 및 건강관련 특성은 실수와 백분율, 평균과 표 준편차로 분석하였다. 여자대학생의 과민성 대장증후군 발생여부에 따라 인구사회학적 및 건강관련 특성, 불안, 우울, 스트레스 지각 정도의 차이는 $\chi^{2}$-test, independent $t$-test 또는 Fisher's exact test를 이용하여 분석하였다. 과민 성 대장증후군 증상의 하위 유형에 따른 불안, 우울, 스 트레스 지각 정도의 차이는 일원배치 분산분석(One-way $\mathrm{ANOVA})$ 을 이용하였다. 불안, 우울, 스트레스 지각 정도 와 과민성 대장증후군 사이의 연관성은 다변량 로지스틱 회귀분석을 실시한 뒤, 교차비(Odds Ratio, OR)를 산출하여 평가하였다. 유의도 $(\alpha)$ 는 0.05 (양측검정)로 판정하였다.

\section{결 과}

\section{대상자의 인구사회학적 및 건강관련 특성 및 과민성 대 장증후군 유병률}

673명의 연구대상자들 중 Rome III 진단기준에 따른 과민성 대장증후군으로 진단받은 환자군은 188 명(27.9\%) 였고, 과민성 대장증후군이 없는 건강 대조군은 485 명 
Table 1. General characteristics of participants $(\mathrm{N}=673)$

\begin{tabular}{|c|c|c|c|c|c|}
\hline \multirow[t]{2}{*}{ Variables } & \multirow[t]{2}{*}{ Categories } & $\begin{array}{c}\text { Total } \\
(\mathrm{N}=673)\end{array}$ & $\begin{array}{l}\text { IBS patients } \\
\quad(\mathrm{n}=188)\end{array}$ & $\begin{array}{l}\text { Healthy controls } \\
\quad(n=485)\end{array}$ & \multirow{2}{*}{$\chi^{2} / t(P)$} \\
\hline & & $\mathrm{n}(\%)$ or $\mathrm{M} \pm \mathrm{SD}$ & $\mathrm{n}(\%)$ or $\mathrm{M} \pm \mathrm{SD}$ & $\mathrm{n}(\%)$ or $\mathrm{M} \pm \mathrm{SD}$ & \\
\hline Age (years) & & $21.0 \pm 1.9$ & $21.1 \pm 1.9$ & $20.9 \pm 1.9$ & $0.98(0.330)$ \\
\hline BMI $\left(\mathrm{kg} / \mathrm{m}^{2}\right)$ & & $20.4 \pm 2.5$ & $20.2 \pm 2.6$ & $20.5 \pm 2.5$ & $-1.31(0.301)$ \\
\hline \multirow[t]{4}{*}{ Year in school } & Freshman & $119(17.7)$ & $36(19.1)$ & $83(17.2)$ & $6.25(0.100)$ \\
\hline & Sophomore & $213(31.6)$ & $46(24.6)$ & $167(34.4)$ & \\
\hline & Junior & $196(29.1)$ & $61(32.4)$ & $135(27.8)$ & \\
\hline & Senior & $145(21.5)$ & $45(23.9)$ & $100(20.6)$ & \\
\hline \multirow{4}{*}{$\begin{array}{l}\text { Residential } \\
\text { status }\end{array}$} & Own house & $385(57.2)$ & $116(61.7)$ & $269(55.5)$ & $3.80(0.284)$ \\
\hline & Dormitory & $190(28.2)$ & $43(22.9)$ & $147(30.3)$ & \\
\hline & Self-boarding & $90(13.4)$ & $27(14.4)$ & $63(13.0)$ & \\
\hline & Others & $8(1.2)$ & $2(1.0)$ & $6(1.2)$ & \\
\hline \multirow{2}{*}{ Alcohol } & Yes & $546(81.1)$ & $158(84.0)$ & $388(80.0)$ & $1.45(0.229)$ \\
\hline & No & $127(18.9)$ & $30(16.0)$ & $97(20.0)$ & \\
\hline \multirow{2}{*}{ Smoking } & Yes & $10(1.5)$ & $1(0.5)$ & $9(1.9)$ & $1.62(0.203)^{*}$ \\
\hline & No & $663(98.5)$ & $187(99.5)$ & $476(98.1)$ & \\
\hline \multirow{2}{*}{$\begin{array}{l}\text { Medical facilities visits } \\
\text { (for } 3 \text { months) }\end{array}$} & Yes & $95(14.1)$ & $36(19.1)$ & $59(12.2)$ & $5.45(0.020)$ \\
\hline & No & $578(85.9)$ & $152(80.9)$ & $426(87.8)$ & \\
\hline \multirow{2}{*}{$\begin{array}{l}\text { Medication } \\
\text { (for } 3 \text { months) }\end{array}$} & Yes & $195(29.0)$ & $81(43.1)$ & $114(23.5)$ & $25.24(<0.001)$ \\
\hline & No & $478(71.0)$ & $107(56.9)$ & $371(76.5)$ & \\
\hline
\end{tabular}

BMI=Body mass index; IBS=Irritable Bowel Syndrome; *Fisher exact test

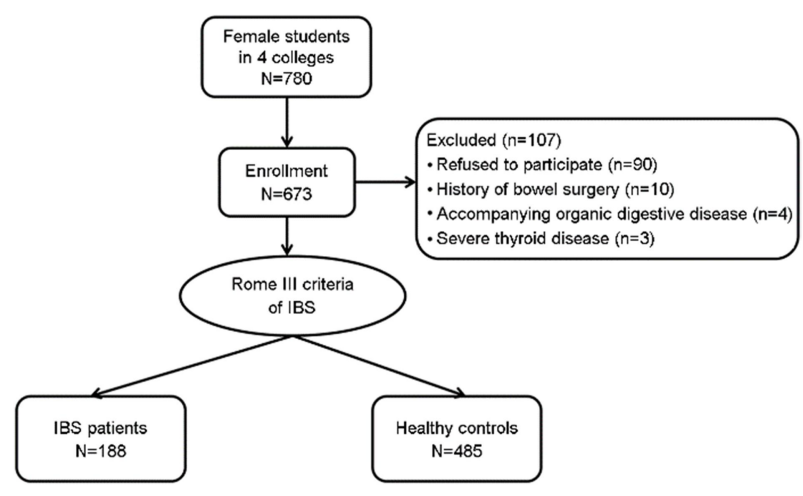

Fig. 1. Flow chart of the study process. IBS: Irritable bowel synrome.

(72.1\%)였다(Fig. 1). 인구사회학적 특성과 건강관련 특성 은 Table 1 과 같다. 모두 여자이며, 연령의 범위는 만 18 세 에서 28세로 평균 연령(표준편차)은 21.0 ( \pm 1.9$)$ 세였으며, 평균 체질량지수(표준편차)는 $20.4( \pm 2.5) \mathrm{kg} / \mathrm{m}^{2}$ 이었다. 참 여 학생의 학년분포는 4 학년 $21.5 \%, 3$ 학년 $29.1 \%, 2$ 학년 $31.6 \%, 1$ 학년 $17.7 \%$ 이었다. 주거형태는 자기 집 거주가
$57.2 \%$ 로 가장 많았고, 음주하는 사람은 $81.1 \%$ 이며 흡연 하는 사람은 $1.5 \%$ 였다. 과민성 대장증후군 환자군과 건 강 대조군 사이에 인구사회학적인 특성에서 유의한 차이 가 없었다. 다만, 최근 3 개월 동안 복통이나 복부 불편감 으로 의료기관을 방문한 경우는 과민성 대장증후군 환자 군에서 $19.1 \%$ 로 건강 대조군의 $12.2 \%$ 에 비하여 통계학적 으로 의미있게 높았다 $(P=0.020)$. 또한, 최근 3 개월 동안 복통이나 복부 불편감으로 약물을 복용한 경우는 과민성 대장증후군 환자군에서 $43.1 \%$, 건강 대조군에서 $23.5 \%$ 로 과민성 대장증후군 환자군에서 월등히 높았다 $(P<0.001)$.

\section{과민성 대장증후군과 불안, 우울, 스트레스 지각 정도}

불안은 과민성 대장증후군 환자군에서 불안하지 않은 상태(8점 미만)가 $53.7 \%$ 로 가장 많았고 경계성 불안(8 10 점)이 $25.0 \%$, 불안한 상태(11점 이상)가 $21.3 \%$ 이었으며, 우울은 과민성 대장증후군 환자군에서 우울하지 않은 상 태(8점 미만)가 $62.8 \%$ 로 가장 많았고 경계성 우울(8 10점) 이 $26.6 \%$, 우울한 상태(11점 이상)가 $10.6 \%$ 이었다. 불안은 과민성 대장증후군 환자군에서 $7.75( \pm 3.45)$ 점, 건강 대조 
Table 2. Differences of HADS and GARS between IBS patients and healthy controls $(\mathrm{N}=673)$

\begin{tabular}{|c|c|c|c|c|c|c|c|c|}
\hline \multirow{2}{*}{\multicolumn{2}{|c|}{ Variables }} & \multirow{2}{*}{$\begin{array}{c}\begin{array}{c}\text { Total } \\
(\mathrm{N}=673)\end{array} \\
\mathrm{n}(\%) \text { or } \\
\mathrm{M} \pm \mathrm{SD}\end{array}$} & \multirow{2}{*}{$\begin{array}{c}\begin{array}{c}\text { IBS patients } \\
(\mathrm{n}=188)\end{array} \\
\mathrm{n}(\%) \text { or } \\
\mathrm{M} \pm \mathrm{SD}\end{array}$} & \multirow{2}{*}{$\begin{array}{l}\text { Healthy controls } \\
(\mathrm{n}=485)\end{array}$} & \multirow{2}{*}{$\chi^{2} / t(P)$} & \multicolumn{3}{|c|}{ Multiple logistic regression } \\
\hline & & & & & & OR & $(95 \% \mathrm{CI})$ & $P$ \\
\hline \multirow[t]{8}{*}{ HADS } & Anxiety & $6.65 \pm 3.52$ & $7.75 \pm 3.45$ & $6.22 \pm 3.46$ & $-5.15(<0.001)$ & 1.07 & $(1.01 \sim 1.15)$ & 0.032 \\
\hline & $<8$ & $438(65.1)$ & $101(53.7)$ & $337(69.5)$ & $16.27(<0.001)$ & & & \\
\hline & $8 \sim 10$ & $138(20.5)$ & $47(25.0)$ & $91(18.8)$ & & & & \\
\hline & $\geq 11$ & $97(14.4)$ & $40(21.3)$ & $57(11.7)$ & & & & \\
\hline & Depression & $5.90 \pm 3.26$ & $6.56 \pm 3.03$ & $5.64 \pm 3.31$ & $-3.33(0.001)$ & 1.00 & $(0.93 \sim 1.06)$ & 0.918 \\
\hline & $<8$ & $481(71.5)$ & $118(62.8)$ & $363(74.8)$ & $11.28(0.004)$ & & & \\
\hline & $8 \sim 10$ & $127(18.9)$ & $50(26.6)$ & $77(15.9)$ & & & & \\
\hline & $\geq 11$ & $65(9.7)$ & $20(10.6)$ & $45(9.3)$ & & & & \\
\hline \multicolumn{2}{|l|}{ GARS } & $30.46 \pm 14.12$ & $43.59 \pm 13.01$ & $25.37 \pm 10.88$ & $-17.02(<0.001)$ & 1.23 & $(1.19 \sim 1.27)$ & $<0.001$ \\
\hline
\end{tabular}

HADS=Hospital Anxiety and Depression; GARS=Global Assessment of Recent Stress; IBS=Irritable Bowel Syndrome

Table 3. Differences of HADS and GARS between IBS subtypes ( $\mathrm{N}=188)$

\begin{tabular}{|c|c|c|c|c|c|c|}
\hline \multirow{2}{*}{\multicolumn{2}{|c|}{ Variables }} & \multicolumn{4}{|c|}{ IBS subtypes $(\mathrm{M} \pm \mathrm{SD})$} & \multirow{2}{*}{$F(P)$} \\
\hline & & IBS-C $(n=85)$ & IBS-D $(n=45)$ & IBS-M $(n=54)$ & IBS-U (n=4) & \\
\hline \multirow{2}{*}{ HADS } & Anxiety & $7.87 \pm 3.80$ & $7.67 \pm 3.18$ & $7.65 \pm 3.25$ & $7.50 \pm 2.52$ & $0.07(0.978)$ \\
\hline & Depression & $6.73 \pm 2.79$ & $6.47 \pm 3.81$ & $6.41 \pm 2.74$ & $6.25 \pm 2.50$ & $0.16(0.923)$ \\
\hline \multicolumn{2}{|l|}{ GARS } & $43.87 \pm 12.56$ & $43.27 \pm 13.85$ & $43.44 \pm 13.58$ & $43.00 \pm 7.96$ & $0.03(0.994)$ \\
\hline
\end{tabular}

HADS=Hospital Anxiety and Depression; GARS=Global Assessment of Recent Stress; IBS=Irritable Bowel Syndrome; IBS-C=IBSConstipation; IBS-D=IBS-Diarrhea; IBS-M=IBS-Mixed type; IBS-U=IBS-Unsubtyped

군에서 $6.22( \pm 3.46)$ 점이였고, 우울은 과민성 대장증후군 환자군에서 $6.56( \pm 3.03)$ 점, 건강 대조군에서 $5.64( \pm 3.31)$ 점으로 두 지표 모두 과민성 대장증후군 환자군에서 높 았다 $(P<0.001, P=0.001)$. 스트레스 지각 정도는 과민성 대 장증후군 환자군에서 43.59 ( \pm 13.01$)$ 점, 건강 대조군에서 25.37 ( \pm 10.88$)$ 점으로 과민성 대장증후군 환자군에서 높았 다 $(P<0.001)$ 불안과 스트레스는 다변량 로지스틱 회귀분 석에서 교차비 $1.07(95 \% \mathrm{CI}=1.01 \sim 1.15, P=0.032)$ 및 1.23 (95\% $\mathrm{CI}=1.19 \sim 1.27, P<0.001)$ 으로 과민성 대장증후군의 독 립적인 위험인자로 나타났다(Table 2).

\section{과민성 대장증후군 증상의 하위 유형과 불안, 우울, 스 트레스 지각 정도}

Rome III 진단기준에 따른 과민성 대장증후군 증상의 하위 유형은 변비형이 85명(45.3\%)으로 가장 많았으며, 다음으로 혼합형이 54명(28.7\%), 설사형이 45명(23.9\%), 미 분류형이 4 명 $(2.1 \%)$ 순이었다. 과민성 대장증후군 증상의
하위 유형 따른 불안, 우울, 스트레스 지각 정도는 변비 형에서 모두 약간 높았으나, 다른 하위 유형과 통계학적 인 차이를 보이지 않았다(Table 3 ).

\section{고 찰}

젊은 여자대학생은 약 4 분의 1 이상에서 과민성 대장 증후군의 증상으로 불편함을 호소하고 있었고, 과민성대 장증후군을 가진 여자대학생들이 불안과 우울을 더 많이 호소하고 스트레스에 대한 지각 정도가 매우 높게 나타 났다. 젊은 여자대학생은 시험과 진로에 대한 스트레스가 심하고, 이로 인한 불안과 우울을 호소하는 경우가 많아 서 신체화 증상을 많이 나타내고 과민성 대장증후군의 유 병률이 높은 것으로 생각된다.

본 연구에서는 여자대학생(평균 연령 21세) 673명을 대 상으로 ROME III 진단기준에 해당하는 과민성 대장증후 군으로 선별된 대상자는 188 명으로 유병률은 $27.9 \%$ 로 나 
타났다. 국내 과민성 대장증후군의 유병률은 3.0 28.0\% 로 추정되고 있는 것과 비교하였을 때 비교적 높은 유병 률인 것을 알 수 있었다(Han et al., 2006; Lee et al., 2009; Park and Lim, 2011). 과민성 대장증후군은 젊은 여성에서 남성보다 3 배 정도 더 많은 것으로 보고되고 있다(Lee et al., 2001; Chang and Heitkemper, 2002). 국내외 여자대학생 을 대상으로 조사한 과민성 대장증후군의 유병률이 $15.7 \%$ 에서 $35.0 \%$ 로 본 연구와 비슷하였다(Jafri et al., 2005; Shiotani et al., 2006; Naeem et al., 2012; Ibrahim et al., 2013; Costanian et al., 2015; Alsuwailm et al., 2017; Park et al., 2018). 이러한 결과는 일반대학생을 대상으로 조사한 과민성 대 장증후군의 유병률이 $10.7 \%$ 인(Shiotani et al., 2006) 것과 비 교하면 젊은 여자대학생의 유병률이 매우 높은 것을 알 수 있다. 젊은 여성에서 남성보다 과민성 대장증후군 유 병률이 높은 이유는 내장 과민성의 역치가 낮고, 대장 통 과시간이 길며, 생리주기에 따른 에스트로겐이나 프로게 스테론, 프로스타글란딘 등 호르몬 변화와 관련 있는 것 으로 알려져 있다(Heitkemper et al., 2003; Kim and Park, 2011).

과민성 대장증후군의 증상 유형은 변비형이 $45.3 \%$, 설 사-변비 혼합형이 $28.7 \%$, 설사형 $23.9 \%$, 미분류형 $2.1 \%$ 순이었다. 국내외의 전체 과민성 대장증후군 환자를 대상 으로 한 선행연구에서는 혼합형이 $50.0 \%$ 에서 $55.7 \%$ 로 가 장 많은 분포를 차지하고 있었고, 젊은 여성을 대상으로 한 연구에서는 변비형이 가장 많은 분포를 차지하고 있 었다(Kim and Ban, 2005; Tillisch et al., 2005; Shiotani et al., 2006; Okami et al., 2011). 증상의 차이가 발생하는 기전에 대하여 명확하게 설명할 수는 없으나 설사형의 경우는 장의 운동성이 과도하며, 변비형의 경우에는 장의 운동성 이 미약하게 발생된다. 결국, 장의 운동성을 조절하는 중 추신경계의 약화로 인하여 일어나는 현상으로, 증상 유형 에 따라 식이, 약물 치료 및 관리 방법을 다르게 해야 한 다(Porcelli, 2004; Drossman and Dumitrascu, 2006).

본 연구의 대상자인 여자대학생의 심리적 고통으로 우 울은 선행연구(Dong et al., 2010)보다 약간 낮았고 불안은 약간 높았으나, 전반적으로 비슷한 수준이었다. 반면, 과 민성 대장증후군 환자군과 건강 대조군으로 나누어 비교 하면 월등히 과민성 대장증후군 환자에서 심리적 고통이 높게 나타났다. 과민성 대장증후군과 정신 질환 간의 관 계를 평가한 여러 선행연구에서 신경증, 불안, 우울증 및 인지 기능 장애가 과민성 대장증후군 환자에서 더 많이 발생하는 것으로 보고되었다(Budavari and Olden, 2003;
Gonsalkorale et al., 2003; Koloski et al., 2003; Levy et al., 2006). 심한 과민성 대장증후군 환자를 대상으로 한 연구에서는 대상자의 $44 \%$ 가 정신병적 증상을 경험한 것으로 나타났 고 우울증과 불안증세가 가장 흔한 질환이었다(Guthrie et al., 2003). 본 연구에서도 불안과 스트레스가 과민성 대장 증후군과 독립적인 상관관계를 보였고, 다른 연구들에서 의 결과와 일치하였다. 124 명의 과민성 대장증후군과 91 명 의 건강 대조군에서 정신적 요인의 상관관계를 비교한 선 행연구에서 불안과 우울은 장 증상의 중등도와 가장 밀 접한 관련이 있었다(Cho et al., 2011). 767명의 남녀 대학생 을 대상으로 한 이전의 연구에서 스트레스가 과민성 대 장증후군 환자에서 높게 나타났다(Liu et al., 2014). 또한, 248 명의 여자 군인을 대상으로 과민성 대장증후군과 심 리적 고통의 관련성을 확인한 연구에서 과민성 대장증후 군이 있는 군에서 불안, 우울, 스트레스가 높은 것으로 나타났다(Savas et al., 2009). 이와 같은 맥락으로 복통, 설 사, 팽만감, 변비, 식욕 부진, 구토 등 6 가지 주요 위장관 증상과 정신 상태의 연관성에 대한 대규모 무작위 연구 에서는, 주요 우울증(13.4\%), 공황 장애(12.5\%) 및 광장 공포증(17.8\%)은 두 가지 이상의 위장관 증상이 있는 환 자에서 더 흔하게 발견되었다(Yates, 2005).

과민성 대장증후군과 정신 질환과의 연관관계는 뇌-장 축(brain-gut axis)의 기능 장애가 중요한 역할을 한다고 알 려져 있다(Bercik et al., 2012; Kennedy et al., 2012). 상향식 모델에 따르면 복부 증상은 이차적으로 불안과 우울증에 영향을 미치고, 하향식 모델에 따르면 스트레스, 불안 및 우울증과 같은 정신적 요인 자체가 미주 및 교감성 신경 을 통하여 장의 운동 기능, 감각 역치 및 스트레스 반응 성과 같은 생리적 요인에 영향을 미친다. 과민성 대장증 후군 환자에서 높은 수준의 불안, 우울, 스트레스에 대한 본 연구 결과는 과민성 대장증후군에서 정신적 요인의 역 할을 더욱 뒷받침한다. 따라서 과민성 대장증후군 환자의 동반 심리적 고통인 불안, 우울, 스트레스를 확인하고 치 료하는 것은 과민성 대장증후군을 더 잘 이해하는 데 도 움이 되고, 더 나은 치료 결과에 기여할 것으로 생각된다. 실제, 과민성 대장증후군 치료를 위해 일반적인 관리와 심리요법을 비교한 19 개 연구와 위약과 항우울제를 비교 한 12 개 연구를 비교한 메타분석에서, 심리요법 및 항우 울제가 과민성 대장증후군의 치료에 상당한 이점이 있음 을 입증했다(Ford et al., 2009).

본 연구에서는 변비형 환자에서 불안, 우울, 스트레스 의 점수가 약간 높았으나 다른 하위 유형을 가진 환자들 
과 비교하였을 때 통계적으로 유의한 차이를 보이지는 않았다. Guthrie 등 (2003)의 연구에 의하면, 설사형 환자에 서 다른 하위 유형에 비해서 높은 정신병적 동반 질환율 을 보고했다. 반면, Eriksson 등 (2008)의 연구에서는 변비 형 환자가 설사형 환자보다 정신적 증상이 더 높았고 혈 청 프롤락틴(prolactin)의 수치가 더 높았다. 그러나 설사 형 환자에서 신체 기능 장애에 대한 인식도는 더 높았고, 높은 C-펩티드(C-peptide) 수치를 보였다. 이는 아마도 자 율신경계 기능 장애를 반영한 것으로 생각된다. 또한, 혼 합형 환자에서는 변비형과 설사형에 관여하는 프롤락틴 과 $\mathrm{C}$-펩타이드가 모두 동시에 존재하는 것으로 보인다. 따라서, 과민성 대장증후군의 하위 유형 간의 차이를 증 명하기 위해 추가 생화학 연구가 필요할 것으로 생각된다.

본 연구는 몇 가지 제한점이 있다. 첫째, 연구의 표본 크기가 지금까지의 선행연구에 비해 비교적 크지만, 무작 위 표집이 아닌 임의 표집으로 하였기에 연구 결과를 여 자대학생에게 일반화하기에 제한적이다. 둘째, 과민성 대 장증후군 Rome III 진단기준으로 젊은 여성에서만 검사하 여 변비형이 가장 많은 빈도로 조사되었다. 그러나, 전체 과민성 대장증후군 환자의 하위 유형 중에 가장 많은 것 으로 알려진 혼합형이기 때문에 본 연구가 일반인구를 대표하지 않을 수 있다. 이에 따라 본 연구에서 불안, 우 울, 스트레스의 점수가 하위 유형에 따른 큰 차이를 보이 지 않았을 가능성이 있기 때문에 젊은 성인에서 성별에 따른 과민성 대장증후군 환자의 하위 유형을 분류하여 심리적 고통과의 관련성을 조사하는 연구가 필요하다. 셋 째, 본 연구에서 반영되지 않은 다른 변수들이 불안 및 우울과 같은 정신 장애의 유병률을 증가시킬 수 있다. 따 라서, 삶의 질, 신체화 장애, 수면의 질과 같은 광범위하 고 복잡한 위험 요소에 대한 더 많은 연구가 필요하며 심리 사회적 작업 조건 간의 연관성에 대해서도 추가적 인 조사가 있어야 한다. 넷째, 본 연구에서는 다른 질환 이 없는 젊은 여자대학생을 대상으로 과민성 대장증후군 진단 도구인 Rome III를 이용했으나 과민성 대장증후군 증상과 유사한 증상을 가진 소화기 질환을 배제하지 못 하였을 위험이 있다. 그러므로 추후 연구에서 과민성 대 장증후군을 배제하기 위한 충분한 모니터링을 포함한 연 구가 필요할 것이다.

본 연구는 젊은 여자대학생에서 과민성 대장증후군의 유병률이 높고, 건강 대조군에 비하여 불안, 스트레스의 정도가 심함을 보여주었다. 과민성 대장증후군의 하위 유 형 중 변비형이 가장 많이 발생하였으나 불안, 우울 및
스트레스 등의 심리적 고통은 하위 유형 간에 차이를 보 이지는 않았다. 젊은 여자대학생에서는 과민성 대장증후 군에 대한 일반적인 치료와 함께 정신적 요인에 대한 조 사와 관리가 동반되어야 할 것이다. 향후, 과민성 대장증 후군 하위 유형과 심리적 고통의 관계를 조사하기 위한 대규모 연구가 추가적으로 수행하여 하위 유형에 따른 치료 방법의 개별화가 필요할 것이다.

\section{ACKNOWLEDGEMENT}

None.

\section{CONFLICT OF INTEREST}

The author has declared no conflict of interest.

\section{REFERENCES}

Adeyemo MA, Spiegel BM, Chang L. Meta-analysis: do irritable bowel syndrome symptoms vary between men and wome? Aliment Pharmacol Ther. 2010. 32: 738-755.

Alander T, Heimer G, Svärdsudd K, Agréus L. Abuse in women and men with and without functional gastrointestinal disorders. Dig Dis Sci. 2008. 53: 1856-1864.

Alsuwailm WA, ALQahtani MM, ALHulaibi AA, ALHadi MA, Ali SI, Shehabeldeen SA. Irritable bowel syndrome among medical students and interns in King Faisal University. Open Journal of Preventive Medicine. 2017. 7: 235-246.

Azpiroz F, Dapoigny M, Pace F, Müller-Lissner S, Coremans G, Whorwell $\mathrm{P}$, et al. Nongastrointestinal disorders in the irritable bowel syndrome. Digestion. 2000. 62: 66-72.

Bercik P, Collins SM, Verdu EF. Microbes and the gut-brain axis Neurogastroenterol Motil. 2012. 24: 405-413.

Berman S, Suyenobu B, Naliboff BD, Bueller J, Stains J, Wong H, et al. Evidence for alterations in central noradrenergic signaling in irritable bowel syndrome. Neuroimage. 2012. 63: 1854-1863.

Budavari AI, Olden KW. Psychosocial aspects of functional gastrointestinal disorders. Gastroenterol Clin North Am. 2003. 32 477-506.

Chang L, Heitkemper MM. Gender differences in irritable bowel syndrome. Gastroenterology. 2002. 123: 1686-1701.

Chey WD, Kurlander J, Eswaran S. Irritable bowel syndrome: a clinical review. JAMA. 2015. 313: 949-958.

Chial HJ, Camilleri M. Gender differences in irritable bowel syndrome. J Gend Specif Med. 2002. 5: 37-45. 
Choung RS, Locke GR 3rd. Epidemiology of IBS. Gastroenterol Clin North Am. 2011. 40: 1-10.

Cho HS, Park JM, Lim CH, Cho YK, Lee IS, Kim SW, et al. Anxiety, depression and quality of Life in patients with irritable bowel syndrome. Gut Liver. 2011. 5: 29-36.

Costanian C, Tamim H, Assaad S. Prevalence and factors associated with irritable bowel syndrome among university students in Lebanon: Findings from a cross-sectional study. World J Gastroenterol. 2015. 21: 3628-3635.

Dong YY, Zuo XL, Li CQ, Yu YB, Zhao QJ, Li YQ. Prevalence of irritable bowel syndrome in Chinese college and university students assessed using Rome III criteria. World J Gastroenterol. 2010. 16: 4221-4226.

Drossman DA. Presidential address: Gastrointestinal illness and the biopsychosocial model. Psychosom Med. 1998. 60: 258 $-267$.

Drossman DA. The functional gastrointestinal disorders and the Rome III process. Gastroenterology. 2006. 130: 1377-1390.

Drossman DA, Dumitrascu DL. Rome III: new standard for functional gastrointestinal disorders. J Gastrointestin Liver Dis. 2006. 15: 237-241.

Esler ME, Coulston KJ. Levels of anxiety in colonic disorders. N Engl J Med. 1973. 15: 165-172.

Eriksson EM, Andrexn KI, Eriksson HT, Kurlberg GK. Irritable bowel syndrome subtypes differ in body awareness, psychological symptoms and biochemical stress markers. World J Gastroenterol. 2008. 14: 4889-4896.

Ford AC, Lacy BE, Talley NJ. Irritable bowel syndrome. N Engl J Med. 2017. 376: 2566-2578.

Ford AC, Talley NJ, Schoenfeld PS, Quigley EM, Moayyedi P. Efficacy of antidepressants and psychological therapies in irritable bowel syndrome: Systematic review and meta-analysis. Gut. 2009. 58: 367-378.

Gonsalkorale WM, Perrey C, Pravica V, Whorwell PJ, Hutchinson IV. Interleukin 10 genotypes in irritable bowel syndrome: evidence for an inflammatory component? Gut. 2003. 52: 91-93.

Guthrie E, Creed F, Fernandes L, Ratcliffe J, Van Der Jagt J, Martin $\mathrm{J}$, et al. Cluster analysis of symptoms and health seeking behaviour differentiates subgroups of patients with severe irritable bowel syndrome. Gut. 2003. 52: 1616-1622.

Han SH, Lee OY, Bae SC, Lee SH, Chang YK, Yang SY, et al. Prevalence of irritable bowel syndrome in Korea: populationbased survey using the Rome II criteria. J Gastroenterol Hepatol. 2006. 21: 1687-1692.

Heitkemper M, Jarrett M, Bond EF, Chang L. Impact of sex and gender on irritable bowel syndrome. Biol Res Nurs. 2003. 5: 56-65.

Hungin AP, Whorwell PJ, Tack J, Mearin F. The prevalence, patterns and impact of irritable bowel syndrome: an international survey of 40,000 subjects. Aliment Pharmacol Ther. 2003. 17: 643-650.

Ibrahim NKR, Battarjee WF, Almehmadi SA. Prevalence and predictors of irritable bowel syndrome among medical students and interns in King Abdulaziz University, Jeddah. Libyan J Med. 2013. 8: 21287.

Jafri W, Yakoob J, Jafri N, Islam M, Ali QM. Frequency of irritable bowel syndrome in college students. J Ayub Med Coll Abbottabad. 2005. 17: 9-11.

Jones M, Koloski N, Boyce P, Talley NJ. Pathways connecting cognitive behavioral therapy and change in bowel symptoms of IBS. J Psychosom Res. 2011. 70: 278-285.

Kennedy PJ, Clarke G, Quigley EM, Groeger JA, Dinan TG, Cryan JF. Gut memories: Towards a cognitive neurobiology of irritable bowel syndrome. Neurosci Biobehav Rev. 2012. 36: 310 -340 .

Kim M, Park H. The process of symptom control in Korean women with irritable bowel syndrome. Gastroenterol Nurs. 2011. 34: 424-432.

Kim YJ, Ban DJ. Prevalence of irritable bowel syndrome, influence of lifestyle factors and bowel habits in Korean college students. Int J Nurs Stud. 2005. 42: 247-254.

Kim YS, Kim N. Sex-gender differences in irritable bowel syndrome. J Neurogastroenterol Motil. 2018. 24: 544-558.

Koh KB. Stress perception of patients with psychosomatic disorders. J Korean Neuropsychiatr Assoc. 1988. 27: 514-524.

Koloski NA, Talley NJ, Boyce PM. Does psychological distress modulate functional gastrointestinal symptoms and health care seeking? A prospective, community Cohort study. Am J Gastroenterol. 2003. 98: 789-797.

Lee OY, Mayer EA, Schmulson M, Chang L, Naliboff B. Genderrelated differences in IBS symptoms. Am J Gastroenterol. 2001. 96: 2184-2193.

Lee SY, Lee KJ, Kim SJ, Cho SW. Prevalence and risk factors for overlaps between gastroesophageal reflux disease, dyspepsia, and irritable bowel syndrome: A population-based study. Digestion. 2009. 79: 196-201.

Levy RL, Olden KW, Naliboff BD, Bradley LA, Francisconi C, Drossman DA, et al. Psychosocial aspects of the functional gastrointestinal disorders. Gastroenterology. 2006. 130: 1447 -1458 . 
Linn MW. A global assessment of recent stress (GARS) scale. Int J Psychiatry Med. 1985: 15: 47-59.

Liu Y, Liu L, Yang Y, Yanli Z, Wang M, Chen S, et al. A schoolbased study of irritable bowel syndrome in medical students in Beijing, China: prevalence and some related factors. Gastroenterol Res Pract. 2014. 2014: 124261.

Lu CL, Chang FY, Lang HC, Chen CY, Luo JC, Lee SD. Gender difference on the symptoms, health-seeking behaviour, social impact and sleep quality in irritable bowel syndrome: a Rome II-based survey in an apparent healthy adult Chinese population in Taiwan. Aliment Pharmacol Ther. 2005. 21: 1497-1505.

Makharia GK, Verma AK, Amarchand R, Goswami A, Singh P, Agnihotri A, Suhail F, Krishnan A. Prevalence of irritable bowel syndrome: a community based study from northern India. J Neurogastroenterol Motil. 2011. 17: 82-87.

Mazurak N, Seredyuk N, Sauer H, Teufel M, Enck P. Heart rate variability in the irritable bowel syndrome: a review of the literature. Neurogastroenterol Motil. 2012. 24: 206-216.

Mearin F, Lacy BE, Chang L, Chey WD, Lembo AJ, Simren M, et al. Bowel disorders. Gastroenterology. 2016. 150: 1393-1407. Muscatello MR, Bruno A, Pandolfo G, Micò U, Stilo S, Scaffidi M, et al. Depression, anxiety and anger in subtypes of irritable bowel syndrome patients. J Clin Psychol Med Settings. 2010. 17: $64-70$

Naeem SS, Siddiqui EU, Kazi AN, Memon AA, Khan ST, Ahmed B. Prevalence and factors associated with irritable bowel syndrome among medical students of Karachi, Pakistan: a cross-sectional study. BMC Research Notes. 2012. 5: 255.

Oh SM, Min KJ, Park DB. A study on the standardization of the hospital anxiety and depression scale for Koreans. J Korean Neuropsychiatr Assoc. 1999. 38: 289-296.

Okami Y, Kato T, Nin G, Harada K, Aoi W, Wada S, et al. Lifestyle and psychological factors related to irritable bowel syndrome in nursing and medical school students. J Gastroenterol. 2011. 46: 1403-1410.

Park H, Lim S. Frequency of irritable bowel syndrome, enterance examination-related stress, mental health, and quality of life in high school students. Gastroenterology Nursing. 2011. 34: 450-458.

Park J, Jung Y, Lee HJ, Seo J. Prevalence and factors related to irritable bowel syndrome in university students. J Korean Acad Fundam Nurs. 2018. 25: 282-292.

Porcelli P. Psychological abnormalities in patients with irritable bowel syndrome. Indian J Gastroenterol. 2004. 23: 63-69.

Rose JD, Troughton AH, Harvey JS, Smith PM. Depression and functional bowel disorders in gastrointestinal outpatients. Gut. 1986. 27: 1025-1028.

Savas LS, White DL, Wieman M, Daci K, Fitzgerald S, Laday Smith S, et al. Irritable bowel syndrome and dyspepsia among women veterans: prevalence and association with psychological distress. Aliment Pharmacol Ther. 2009. 29: 115-125.

Shiotani A, Miyanishi T, Takahashi T. Sex differences in irritable bowel syndrome in Japanese university students. J. Gastroenterol. 2006. 41: 562-568.

Song KH, Jung HK, Min BH, Youn YH, Choi KD, Keum BR, et al. Development and validation of the Korean Rome III questionnaire for diagnosis of functional gastrointestinal disorders. J Neurogastroenterol Motil. 2013. 19: 509-515.

Spiegel BM. The burden of IBS: Looking at metrics. Curr Gastroenterol Rep. 2009. 11: 265-269.

Sugaya N, Nomura S, Shimada H. Relationship between cognitive factors and anxiety in individuals with irritable bowel syndrome Int J Behav Med. 2012. 19: 308-315.

Tanaka Y, Kanazawa M, Fukudo S, Drossman DA. Biopsychosocial model of irritable bowel syndrome. J Neurogastroenterol Motil. 2011. 17: 131-139.

Thomson S, Dancey CP. Symptoms of irritable bowel in school children: prevalence and psychosocial effects. J Pediatr Health Care. 1996. 10: 280-285.

Tillisch K, Mayer EA, Labus JS, Stains J, Chang L, Naliboff BD. Sex-specific alterations in autonomic function among patients with irritable bowel syndrome. Gut. 2005. 54: 1396-1401.

Whitehead WE, Palsson O, Jones KR. Systematic review of the comorbidity of irritable bowel syndrome with other disorders: what are the causes and implications? Gastroenterology. 2002. 122: $1140-1156$

Yates WR. Gastrointestinal disorders. In: Sadock BJ, Sadock VA, editors. Kaplan and Sadock's Comprehensive Textbook of Psychiatry. 8th ed. 2005. p. 2117-2118. Lippincott Williams. Philadelphia, USA.

Zigmond AS, Snaith RP. The hospital anxiety and depression scale. Acta Psychiatrica Scandinavica. 1983. 67: 361-370.

https://doi.org/10.15616/BSL.2020.26.4.351

Cite this article as: Jang A. Prevalence of Irritable Bowel Syndrome and its Association with Psychological Distress among Female College Students in Korea. Biomedical Science Letters. 2020. 26: 351-359. 